\title{
Programas e Compêndios de Direito
}

Ruy Barbosa Nogueira

Titular do Departamento de Direito Econômico e Financeiro e presidente do IBDT/USP

\begin{abstract}
RESUMO: O ex-Diretor da Faculdade de Direito e atual titular do Departamento de Direito Econômico e Financeiro, constantemente convidado a solucionar processos de transferências de alunos para outras faculdades, faz uma explanação sobre a desarmonia existente nas programaçōes dos diversos estabelecimentos de ensino jurídico no País, prejudicando, desta maneira, alunos e candidatos que têm a obrigação de longas adaptações. Preocupado com os problemas, o autor tem realizado constantes debates no Instituto Brasileiro de Direito Tributário (IBDT), entidade complementar à Universidade de Sāo Paulo, do qual é seu presidente.
\end{abstract}

Durante quarenta anos de trabalho no ensino jurídico e experiência não só profissional, mas na chefia do Departamento de Direito Econômico e Financeiro, na Diretoria da Faculdade, na presidência da Comissão de Legislação e Recursos da USP, na responsabilidade por tantos cursos extracurriculares. de extensão, de graduação, de especialização, de mestrado como de doutorado, constantemente temos sido chamado a solucionar processos de transferências de alunos, de uma para outra faculdade, como ainda de revalidação de diplomas ou de reconhecimentos de títulos obtidos ou de cursos realizados em diferentes estabelecimentos de ensino jurídico do Brasil ou de outros países.

Este trabalho nos tem permitido conhecer, em extensão e profundidade, a desarmonia das programaçōes dos diversos estabelecimentos de ensino jurídico. $\mathrm{O}$ que mais nos tem preocupado no desencontro de programas é o quanto isto tem prejudicado aos alunos e candidatos, pois ficam obrigados a longas adaptações ou não conseguem reconhecimento de seus estudos, pela deficiência ou marcantes divergências entre os respectivos programas.

Eis um problema que, a nosso ver, somente a ciência, consciência, companheirismo e altruística ou máxima doação da melhor intencionalidade dos professores universitários de cada ramo do Direito pode, até certo ponto, humana e humanísticamente solucionar.

Há cerca de vinte anos, quando tivemos a idéia de reunir em nossa casa os primeiros colegas de ensino universitário, de profissão e alunos e que, após implementadas estas reuniōes as levamos para a Universidade, a título de Mesa 
Semanal de Debates, dando origem à mais abrangente e, quiçá mais duradoura instituição, que é o INSTITUTO BRASILEIRO DE DIREITO TRIBUTÁRIO (entidade complementar à USP), sempre tivemos esse objetivo de convergência, não só do aprendizado para todos nós, como da harmonização das programações de ensino.

Se há cerca de 40 anos vínhamos sozinho dando cursos extracurriculares a centenas de alunos e tivemos a ventura de obter a primeira cátedra de Direito Tributário, hoje podemos contar com o companheirismo de muitos colegas deste ensino dentro da Universidade e, já para os últimos cursos de extensão universitária somos cerca de 15 professores voluntários dentro do IBDT/USP, podendo agora ainda contar com os consócios fundadores, associados e sócios honorários deste Instituto, tanto do Brasil quanto do exterior, dentro dessa união de esforços.

Todos estes companheiros, por suas qualificações e dedicação ao estudo e ao ensino da tributarística estão igualmente empenhados não só na harmonização, unificação e maior expansão, como aprofundamento gradativo desses estudos.

Acontece que, precisamente neste sentido, acabamos de receber um dos mais notáveis e dedicados professores de Diretto Tributário deste orbe, Klaus Tipke, autor dos mais completo e sempre atualizado compêndio sistematizado de Direito Impositivo (STEUERRECHT-Ein systematische Grundiss, 10. völlig überarbeitete Auflage, Verlag, Dr. Otto Schmidit KG-Köln, 1985, 710 págs.), no qual o grande Mestre e consócio do IBDT/USP publica um acordo de DIRETRIZES, precisamente neste sentido de harmonização e uniformização da matéria tributária que deve ser objeto de ensino.

O que, sobretudo, é admirável nesse consenso, é que os Mestres da República Federal da Alemanha não se limitaram a convocar apenas seus patrícios, mas também eminentes colegas de vários outros países, dando assim a esse desideratum extensão mundial, a que aderimos.

Vamos traduzir do original e aqui divulgar tais DIRETRIZES, ressalvando que, na parte dos tributos em espécie, procuramos adaptá-las ao quadro dos tributos vigentes no Sistema Tributário Nacional, e portanto o item 4 não é tradução, mas adptação. Os grifos em relação à conscientização do Estado de Direito e outros também serão dessa tradução parcial, e não incluiremos o item 5 porque ele trata do exame escrito e oral, quando no Brasil infelizmente, foi abolido o exame oral. 


\section{DIRETRIZES PARA O ENSINO \\ JURÍDICO-TRIBUTÁRIO \\ (DIRETRIZES DE DÜRNSTEIN)}

Nos programas dos estudos jurídicos e regimentos de exames dos estados da República Federal da Alemanha, atualmente a disciplina "Direito Tributário" é incluída como disciplina de ensino e exames, num contexto especial.

Para harmonizar e uniformizar a matéria a ser lecionada com as exigências feitas nos exames desta disciplina, doze professores universitários de direito tributário da República Federal da Alemanha, membros da Sociedade Alemã dos Tributaristas, assessorados por tributaristas da Áustria, da Suíça, dos Países Baixos, do Japão e da Suécia, num seminário em Dürnstein, perto de Viena, ... acordaram as diretrizes abaixo reproduzidas. Outros oito professores universitários de Direito Tributário aderiram.

1. O ensino do direito tributário nas universidades deve introduzir, através de exemplos, no sistema, nos princípios e métodos de aplicação do direito tributário, tomar consciente as exigências do estado de direito em relaçāo à legislaçāo tributária, apresentar fins e efeitos da intervenção tributária, dar uma visão geral dos impostos em espécie e do procedimento de tributação, bem como transmitir o conhecimento dos mais importantes tributos em espécie.

Deverá acentuar as correlações do direito tributário com outras partes da ordem jurídica.

2. Objeto de ensino do direito tributário são o Direito Tributário Geral e as partes essenciais do Direito Tributário Especial (tributos em espécie).

3. No Direito Tributário Geral, devem ser transmitidos conhecimentos sobre as bases constitucionais da tributação, a posição do direito tributário no sistema do direito, a distinção dos impostos dos demais tributos, bem como os fins e efeitos da intervenção tributária e dos incentivos ou benefícios fiscais.

Deve ser feita a introduçāo nas peculiaridades das fontes do direito tributário e dos métodos de interpretação e aplicação do direito tributário, devendo ser tratadas a estrutura do fato gerador e isenções, bem como a relaçāo jurídico-tributária e as peculiaridades do procedimento de tributação. 
4. No Direito Tributário Especial, devem ser tratadas, aprofundadamente, o imposto de renda da pessoa física, o imposto de renda da pessoa jurídica e do ICM.

Além disso, deve ser apresentada a estrutura do ISS e do imposto sobre herança e doações.

O tratamento da tributação das empresas deve formar um ponto principal de exemplo; para compreensão do conceito de lucro, devem ser transmitidos a estrutura de um balanço, bem como os princípios gerais do balanço e da avaliação.

Em relação ao demais tributos, deve ser dada uma visão geral.

Como o leitor poderá constatar de nosso compêndio didático CURSO DE DIREITO TRIBUTÁRIO, Ediçāo Saraiva, embora seja ele um manual de introdução, desde sua $1^{\mathfrak{a}}$ edição, e talvez porque estivemos sempre em contato com aqueles Mestres, sempre tratamos dessas instituições básicas, sendo que o estudo dos tributos em espécie, fazemos pelo sistema dinâmico dos "casos e problemas", como indicados no último capítulo, para podemos acompanhar, "pari passu", as alterações que no Brasil tem sido quase diárias, tanto assim que tivemos a idéia de, com os colegas, fundar a Mesa Semanal de Debates de Casos e Problemas Tributários e publicar seus trabalhos em seguidas coletâneas, precisamente sob a denominação também dinâmica de DIREITO TRIBUTÁRIO ATUAL (Editora Resenha Tributária e IBDT/USP, S. Paulo, já publicado até o vol. 5).

Sem dúvida, os trabalhos de sistematização e harmonização, nesse campo tão casuístico, precisam de maior cooperação de todos e especialmente daqueles que, como Professores desse ensino e organizadores dos respectivos programas ou escritores de compêndios didáticos que procuram explicitar os programas nunca se esqueçam, dentro deste país continental e federativo, de que os alunos também se transferem não só de faculdade para faculdade, como de cidade para cidade e também de Estado para Estado e que a programação precisa ser o quanto possível uniformizada em torno da unidade do Direito. 